\title{
Teachers' Knowledge of English Young English Learners In the Indonesian Context
}

\author{
Syahrial Karea \\ Fakultas Keguruan dan Ilmu Pendidikan, Universitas Jambi, Indonesia \\ syahrialzakariyya@yahoo.com.au
}

\begin{abstract}
Teachers' knowledge of the characteristics of their students, including English language young learners is important in supporting successful learning. This paper discusses teachers' knowledge of English learners in Jambi city of Indonesia. Thirteen secondary-trained EFL teachers teaching English to children at nine selected primary schools in Jambi were interviewed for data collection. A thematic data analysis conducted revealed that these teachers recognised several specific characteristics of primary school children that underlined their teachings such as innocence, curiosity in learning, limited attention span, and active user of English.Few themes emerging from responses of the participants relate to Indonesian cultural values, and others described characteristics of child's development.
\end{abstract}

Keywords: secondary-trained EFL teachers, knowledge of learners, school children, children's characteristics

\section{INTRODUCTION}

This study was motivated by the fact that most of English language teachers of primary schools in Indonesia are secondary-trained EFL teachers; they have not been specially trained to teach English to primary-age children (Suyanto, 2004) as there is no Indonesian teacher education program that specially prepares English language teachers for primary schools. However, although not trained for primary school contexts, many of these teachers have been successful in helping children learn English. This study investigated how these successful teachers view their students. Darling-Hammond (2006) argues that to carry out an effective teaching, teachers need to learn students' characteristics such as needs, interests, cognitive, and socio-emotional development. For Indonesian context, research investigating such issue is significant as the government has been promoting the use of student-centred approach along with constructivism theory in the current national curriculum. The specific question this research addressed was "How do secondarytrained EFL teachers' view primary school children as foreign language learners?" To address this question, thirteen successful EFL teachers from nine selected schools in Jambi were interviewed.

\section{LITERATURE REVIEW}

Interactionism and young learners' characteristics

A current theory that explains how languages are learned is "interactionism" (Lightbown \& Spada, 2013). Interactionism is derived from cognitive development theory (Piaget, 1970) and sociocultural theory (Vygotsky, 1978a). Advocates of this theory believe that children are lively thinkers as learners; children develop an understanding of the world (including language) based on their interactions within their social environments. Adults help children to perform a higher level of learning and language use in their "zone of proximal development" ( $p$. 86 ). This theory has become the foundation of a teaching strategy, scaffolding advocated by Bruner (1983).

Beside language learning theories, EFL teachers of primary schools need to know children's characteristics developing in social contexts to work effectively in primary classrooms(Darling-Hammond, Bransford, \& LePage, 2005; McKay, 2006). Such characteristics play important roles for selecting appropriate teaching strategies, designing syllabus and language activities and choosing assessment methods that centre on children(Halliwell, 1992). Primary school children bring to classrooms "their own personalities, likes, dislike, interests, their own individual cognitive styles and capabilities, and their own strengths and weaknesses" (McKay, 2006, p. 5).Children of lower grades (1, 2, and3) for example, are at the level of preoperational stage (Piaget, 1983). Their attention span at this stage is very short, ranging from 10 to 15 minutes (McKay, 2006). Children in lower grades learn from direct experience to develop an understanding of cause and effect. They think concretely and are unable to engage in operational thinking (McKay, 2006). They are more interested in process than the product (Brumfit, Pincas, \& Broughton, 2003). They learn more by doing than by listening, and they are able to sort and categorise. Children of grades 4, 5 and 6enter the concrete operational stage (Piaget, 1983). Their experiences of the world expand and their ability to think grows; their ability to reason systematically and logically increases (DeHart, Sroufe, \& Cooper, 2004). They may interpret the same thing differently as they derive an understanding from direct experiences of different contexts (Slavin, 2012). Socio-emotional characteristics of primary school children are central to effective EFL teaching. For example, EFL teachers should provide a learning environment that is psychologically safe and relaxed, free from anxiety but enable risk taking. EFL teachers need to 
vary language activities and presentation styles; create interesting and challenging language tasks by including fantasy materials; and incorporate physical involvements in the activities (Dörnyei, 2001).

Another important characteristic of children involves the various interests they possess. Children's interests affect their attention span, their engagement in learning, and achievement (Halliwell, 1992). Children come to school with a built-in set of interests; it is essential to recognise and consider this aspect in the process of curriculum design, material development and selection of teaching strategies(Halliwell, 1992). Lower grade children learn L2 through listening, and practising in similar ways to their acquisition of L1(Slatterly \& Willis, 2003). They learn language through playing in contexts to unconsciously absorb new vocabulary of the language(Browne, 2007).

\section{METHODS}

This research was a qualitative study investigating English teachers' knowledge about characteristics of young learners learning English in primary schools. For this purpose, thirteen secondary-trained EFL teachers with the teaching experience ranging from5 to 25 years of nine selected primary schools in Jambi City Indonesia agreed to take part in the study(Patton, 2002). These teachers were not specifically trained for teaching English to young children in primary schools. Semi-structured interviews with guidelines and open-ended questions were designed and used to collect the research data from the participants for an analysis. Specific questions after general ones were asked to the participants to elicit their views of characteristics of primary school children. Relevant questions were developed during the conversations depending on the depth of responses the participants provided (Dörnyei, 2001). Participants' responses to the interview questions were electronically recorded and transcribed into texts for the analysis. The data were analysed thematically. Responses from the participants were coded, grouped into themes and interpreted using related literature review.

\section{RESULTS AND DISCUSSIONS}

The thematic analysis identified eight themes emerging from the interviews. Several themes are related to Indonesian cultural values, and others correspond to the characteristics of child's cognitive and socio-emotional development. In the current paper, the themes are presented in order from the most to the least highly rated as discussed by the research participants during the interviews. Throughout this paper, the participants are represented as P1 for participant 1, P2 for participant 2, P3 for participant 3 and so on. The followings are themes emerging from the participants' responses to the interview questions.

Theme 1: Primary school-age children are innocent
The most common characteristic of primary children discussed by the participants in the interviews was innocent (lugu). Nine participants described such characteristic in their responses. For example, P2 stated, "Children are innocent" (P2, personal communication, April 9, 2012). She assumed that primary school students are innocent, honest, and obedient as explained in the "Kamus Besar Bahasa Indonesia" (Shadily \& Echols, 1992). Because children are innocent, P2 enjoyed her teaching in primary schools.

Participants' perceptions describing primary school children as innocent beings may be rooted from the Indonesian culture. Innocence is directly translated from an Indonesian word "lugu", which normally describes the specific nature or quality of children in Indonesia. In the Indonesian context, young children are believed to be lugu, which means honest, obedient, friendly, courteous, and respectful(Sugono, 2008). During the interviews, nine participants described children with this word. The word lugu that describes a special quality of children in Indonesia is very common. Many children's stories use the word in their titles to describe the honesty of the characters. Such word is used in the stories to inculcate the quality of honesty in children. For example, "Si Lugu Baik Hati Akhirnya Jadi Pemimpin Tiran" (Taymur, 1950) and "Si Lugu dan Si Malin Kundang" (Rangkuti, 2007). Lugu is also related to an Islamic term in Indonesia, in which children are often associated with "plain fabric" or "plain paper" (Bukhari, 2013) meaning a "blank slate". P2 stated, "I think it is easier to fill in "blank slates" [primary school students] rather than to fill in those who already have installed something on them minds [such as secondary school students]" (P2, personal communication, April 9, 2012). Indonesian people also often refer to young children as young bamboos, which can be crafted relatively easy to form something useful(Abbas, 2013). Thus, for Indonesian teachers to believe children as honesty, blank slates, plain fabric and young bamboos, meaning easy to be educated and taught, is very common.

\section{Theme 2: Primary school-age children have a variety of} interests

The theme "primary school students have a variety of interests" describes one of general learners' features, not merely children as young EFL learners. Eight participants stated that primary school students have a variety of interests, which means that they need a variety of learning materials and language activities to learn English effectively. For example, P6 said, "Primary school students are varied in terms of interests in learning materials, I need to prepare a variety of learning materials to cover such interests" (P6, personal communication, March 3, 2012). Similarly, P8 described, "Because young students have different interests in every class, I need to modify the learning materials and language activities provided in the course books to address such interests" (P8, personal communication, April 7, 2012). 
The understanding of the various interests of young learners or students is important to teaching and learning in general (Dewey, 1913). This finding is essential to EFL teachers in primary schools as it is relevant to the importance of using children's interests in developing a thematic EFL curriculum or syllabus as discussed in the literature. To understand that young primary school students have a variety of interests is central to effective EFL teaching in primary schools. Many language experts discussed that EFL teachers need to analyse interests of primary school students before they construct learning curriculum or syllabus and prepare learning materials and language activities for the learners. Teachers need to become diagnosticians of children's interests and ideas in order to engage them in explorations of subject matter that extend the reach of their understanding (DarlingHammond et al., 2005). EFL teachers in primary schools need to deeply understand the different interests of their students in order to engage them in various language learning opportunities through different kinds of EFL materials and language activities to extend children's language output. If the EFL materials and activities are varied, they become interesting to young children, and their motivation to learn EFL can be improved and maintained. A lot of research have shown that primary school children's interest towards learning materials and language activities influences their intrinsic motivation and attention span which is central to effective learning (Hidi \& Renninger, 2010). Many studies have also shown that primary children's interest is related to learning efficacy or effective instruction (Wood, Bruner, \& Ross, 1976). Therefore, knowing the different interests of young children inform EFL teachers of primary schools to carry out child-centred EFL teaching (Darling-Hammond \& Barron, 2008; Dewey, 1913; Hidi \& Renninger, 2010; Krapp, 1999).

\section{Theme 3: Primary school-age children learn English from meaning and words, not from rules}

Eight of the participants stated that children learn English from meaning and words rather than from abstract rules. For example, P1 stated:

I don't know how primary school students learn English exactly. However, what I observe every day in the classroom is that students begin from learning meaning and words; I observe they memorise those words, and amazingly they can tell almost every word I have taught them (P1, personal communication, March 29, 2012).

Similarly, P6 said, "I think primary school students begin from learning the meaning of words, and I see that they always check meanings of difficult words using their bilingual dictionaries. I see, they learn meanings of words quickly" (P6, personal communication, March 3, 2012); and P11 explained, "I think young children learn English from meaning embedded in words and I see them pronounce those words repeatedly and loudly" (P11-S7, personal communication, March 31, 2012).
In addition to learning meaning from words, three participants also stated that children do not learn English from abstract rules. For example, P9 stated, "Children do not learn anything from abstract rules, so we need to demonstrate to them how language works; we engage them in actions, interactions, and demonstrations of how language is used in contexts" (P9, personal communication, April 16, 2012). Similarly, P4 stated, "If we teach primary school children English through rules, they will never be successful in learning the language, ... language rules are abstract to them, they just get frustrated and bored instead" (P4, personal communication, April 2, 2012).

The current theme is relevant to the comprehensible input hypothesis (Krashen, 1985) who stated that during the language acquisition process, children will always look for meaning, and thus, vocabulary within which meaning is embedded becomes the most important input to second language learners. Vocabulary as a language input must be comprehensible to children. When the new language is comprehensible, second language learners will process it and then hold it in their memory. Primary school children will learn a second language (English) only when they receive comprehensible input (such as vocabulary), which contains exemplars of the language a little above their current understanding, but from which they can infer meaning (Krashen, 1982, 1985).

This finding is essential to EFL teachers who introduce English to children in primary schools in Indonesia. Indonesian EFL teachers need to prepare language activities that help young children improve their vocabulary. The language input (such as vocabulary) must be comprehensible to them. One way to make the language input (vocabulary) comprehensible to young primary school children is to recycle the vocabulary they already learned(Ellis, 1985). For example, EFL teachers have to utilise "here and now" oriented topics such as a story of everyday life and surrounding environment supported by familiar vocabulary, word games and so on. Using this strategy, young children are enabled to use the linguistic and extra-linguistic contexts and also their general knowledge to interpret the language directed to them (Ellis, 2009). In addition, EFL teachers of young learners also need to prepare language activities that focus more on the process rather than on the product (Ellis, 2009).

\section{Theme 4: Primary school-age children need to feel happy} to learn EFL effectively

Seven participants of the study highlighted that primary school children need to feel happy in classrooms to work productively. For example, P2 stated "we make sure that children feel secure and happy" (P2, personal communication, April 9, 2012). P4 stated, "Children need to feel happy and secure in the classroom to learn effectively" (P4, personal communication, April 2, 2012). $\mathrm{P} 8$, also stated "my experience was telling me that primary 
school children need to feel happy to learn English effectively (P8, personal communication, April 7, 2012).

This finding is central to effective EFL teaching to children in primary schools. It has been noted that in the classroom setting, primary school students need to feel secure or to feel safe to learn a second language effectively (Harder, 2009; McKay, 2006). When children feel safe, they will feel free to explore and play with the second language being learned and hence acquire it. Moreover, feeling secure offers young school students opportunities to learn how to interact with others and respect other children (Harmer, 2010). Therefore, Indonesian EFL teachers need to be ready with positive encouragement.

Theme 5: Primary school-age children are curious to learn English

Six participants of the study mentioned that primary school students were curious to learn English. Excerpts of their comments describing this theme "primary school students are curious to learn English" are summarised as follows.

P1 stated, "Students of primary schools have high curiosity to know about English" (P1, personal communication, March 29, 2012). P5 said, "I think primary school students have stronger curiosity to learn English compared to secondary school students. I think that one thing that makes EFL teaching in primary schools more successful than those in the secondary schools is that primary school students have strong curiosity and better motivation to learn English" (P5, personal communication, April 2, 2012). Similarly, P9 said, "students of primary schools have strong curiosity to learn English". P10 stated, "Primary schools children have strong curiosity and eagerness to learn English" (P10, personal communication, April 16, 2012).

The current theme is relevant to the discussion of curiosity in the teaching literature. Research shows that curiosity, an aspect of intrinsic motivation, has great potential to enhance children's learning (Ryan \& Deci, 2000). It is the motivational component behind children's exploration that has both positive and negative influences on children's behaviours (Baxter \& Switzky, 2008). Many studies that have explained the role of curiosity in child learning noted that curiosity attached to children drives their impulse to learn anything. Most studies dealing with curiosity are related to science learning (Engel, 2011), but inferences can be drawn to EFL learning too.

This finding is important for Indonesian EFL teachers who introduce English to young children in primary schools, particularly for preparing language materials, language activities and designing language tasks for young children. As has been noted, the concept of curiosity has been used in contemporary approaches to language teaching (Ur, 1996). For example, "Communicative Language Teaching" (or CLT) uses such concept for "fill the gap task", in which a text, has certain words replaced with a gap is presented to learners; such a task is said to be based on the curiosity concept. The curiosity concept is also used in "information gap" tasks which are thought to be particularly good at generating student interest. More complex language teaching methods that involve evoking student's curiosity have been adapted for use in foreign and second language teaching. The "Task-Based Language Learning" (Prabhu, 1987) or "Task-Based Language Teaching" (Nunan, 2004), and "Problem-Based Learning" (Barrett, Mac Labhrainn, \& Fallon, 2005) all have used the concept of curiosity in providing second language learners with language activities in classroom learning. These methods have become important methods in language teaching.

Theme 6: Primary school-age children are respectful to teachers

Five out of the thirteen participants participated in the study stated that primary school students are more respectful to teachers compared to secondary school students. P1 said, "Primary school students respect teachers better than secondary school students" (P1, personal communication, March 29, 2012). P2 stated, "primary school students respect me better than secondary school students, they love me very much" (P2, personal communication, April 9, 2012). P12 similarly stated, "Primary school students respect me more than the secondary school students" (P12, personal communication, April 16, 2012). Likewise, P13 also stated, "Primary children are friendlier and more respectful to teachers compared to secondary students; when I enter my class, all children always greet me respectfully" (P13, personal communication, April 27, 2012).

Dewey (1913) argued that respect for teachers is necessary, but it must be based on attention to children's educational progress, meaning that in turn teachers should pay attention to the interest of children. Dewey (1913) wrote that the child's interests, impulses, and desires contribute to shaping his/her destination and provide energy for the engagement in learning. Therefore, while teachers should be respected by children, they must offer appropriate experiences that engage children in desirable challenging learning (Dewey, 1913). This finding is very critical to the Indonesian context, so EFL teachers of young learners in Indonesia, to realise the importance of the learner-centred approach to be seriously implemented in classroom practices.

\section{Theme 7: Primary school-age children are active English} users

Four participants of the study stated that primary school students are active users of English. They stated that the level of engagement of primary school students in language learning activities is better when compared to secondary school students.P5 stated:

The way primary school students learn English, which I observe, is through active learning in using the language. They talk to their buddies in English ... they speak to me in English (P5, personal communication, April 2, 2012). 
P12 asserted, "Children at this school are active English learners ... they use English for asking questions" (P12, personal communication, April 16, 2012). P6 commented, "Children at this school are active English learners" (P6, personal communication, March 3, 2012).

This theme is relevant to a characteristic of children in learning. In a secure condition, children are believed to have less anxiety in learning compared to adult learners. This study found out that children were eager to use English with their buddies and teachers as they were in a secure situation, talking to familiar persons and pushed by their curiosity as discussed above. This finding is important to Indonesian primary school EFL teachers. It informs them that their teaching should involve children with more language activities that provide children with oral language practices. Language activities they prepare need to provide children oral tasks rather than other exercises. Brown (2001) proposed that EFL teachers for young learners should include in children's oral practices physical activities that are parts of children's natural play. This suggestion is an implementation of the constructivism theory for teaching that suggests that young children learn through their own individual actions and explorations(Piaget, 1983; Vygotsky, 1978a). Young children's language development is a result of their social interactions with others (Vygotsky, 1978b). Therefore, oral language tasks for young children require activities that involve physical movement to stimulate their thinking to acquire the target language(Brumfit, 1991).

\section{Theme 8: Primary school-age children have a short} attention span

Three out of thirteen participants mentioned that children cannot concentrate on language tasks as long as secondary school students. They stated that the longest time primary school age children could fully concentrate only ranged between 15 to 30 minutes. P9 stated, "Primary school students can only focus on a particular task within a very limited time span; a fifteen minutes period is the maximum time primary school students can concentrate on a task" (P9, personal communication, April 16, 2012). P10 stated, "Each session should not be more than 30 minutes as primary school students can only concentrate on language tasks within this time span" (P10, personal communication, April 17, 2012); and P11 said, "Primary school students can only concentrate on learning tasks about 30 minutes at the longest" (P11, personal communication, March 31, 2012).

This finding is consistent with the results of several studies in language teaching. Hildreth (1950) argued that for primary school students immobilising their bodies and regarding an object fixedly with their eyes for a period of more than fifteen minutes is a difficult task, tedious and tiring. Primary school children need activities rather than sitting still. However, Brown (2001) commented that the short attention issue appears only when children are not engaged in their learning, therefore the choice of activity is a crucial factor. Enjoyable activities such as drama, roleplay, games, and so on, which interest children can keep them focused on language tasks longer (Brown, 2001; Rixon, 1991).

\section{CONCLUSION}

The current paper has discussed children's characteristics learned by secondary-trained EFL teachers and their implications for teaching English at the primary school level in Indonesia. The participants discussed different children's characteristics based on what they observed in their everyday classes. The study identified several characteristics of young English learners including innocence, curiosity in learning, limited attention span, and active user of English.The participants seemed to learn some important children's characteristics central to successful English teaching to young learners in primary schools.

\section{REFERENCES}

Abbas, I. (2013, 6 ${ }^{\text {th }}$ March). Rebung, bambu, dan disiplin siswa. Haluankepri.

Barrett, T., Mac Labhrainn, I., \& Fallon, H. (2005). Handbook of enquiry and problem-based learning: Irish case studies and international perspectives $\mathrm{T}$. Barrett, I. Mac Labhrainn, \& H. Fallon (Eds.),

Baxter, A., \& Switzky, H. N. (2008). Exploration and curiosity. Elsevier Inc.

Brown, H. D. (2001). Teaching by principles: An interactive approach to language pedagogy (2 ed.). New York: Longman.

Browne, A. (2007). Teaching and learning communication, language and literary (1 ed.). London: Paul Chapman Publishing.

Brumfit, C. (1991). Introduction: Teaching English to children. In C. Brumfit, J. Moon, \& R. K. Tongue (Eds.), Teaching English to children: From practice to principle. Harlow: Longman.

Brumfit, C., Pincas, A., \& Broughton, G. (2003). Teaching English as a foreign language (Third ed.). London: Routledge.

Bruner, J. S. (1983). Child's Talk: Learning to use language. Oxford: Oxford University Press.

Bukhari, I. (2013). Sahih al Bukhari Retrieved from http://www.searchtruth.com/hadith_books.php

Darling-Hammond, L. (2006). Constructing 21st-century teacher education. Journal of Teacher Education, 57(10), 1-15. doi:DOI: 10.1177/0022487105285962

Darling-Hammond, L., \& Barron, B. (2008). How can we teach for meaningful learning? Powerful learning: What we know about teaching for understanding. USA: Jossey-Bass.

Darling-Hammond, L., Bransford, J., \& LePage, P. (2005). Introduction. In L. Darling-Hammond \& J. Bransford (Eds.), Preparing teachers for a changing world: 
What teachers should learn and be able to do. San Francisco, California: Jossey-Bass a Wiley imprint.

DeHart, G. B., Sroufe, L. A., \& Cooper, R. G. (2004). Child development: Its nature and course (5 ed.). Boston, New York: McGrow Hill.

Dewey, J. (1913). Interest and effort in education. Boston, NY, Chicago: Houghton Mifflin Company.

Dörnyei, Z. (2001). Teaching and researching motivation. Harlow: Longman.

Ellis, R. (1985). Understanding second language acquisition. Oxford: Oxford University Press.

Ellis, R. (2009). The Methodology of Task-Based Teaching. The Asian EFL Journal.

Engel, S. (2011). Children's Need to Know: Curiosity in Schools. Harvard Educational Review, 81(4), 625645.

Halliwell, S. (1992). Teaching English in the primary classroom. London: Longman Group UK.

Harder, A. (2009). The developmental stages of Erik Erikson. Altadena: Support4Change.

Harmer, J. (2010). How to teach English (6 ed.). Harlow, Essex: Pearson Education Ltd.

Hidi, S., \& Renninger, K. A. (2010). The Four-Phase Model of Interest Development. Educational Psychologist, 41(2), 111-127.

Hildreth, G. (1950). Readiness for school beginners. Yonkers-on-Hudson, New York: World Book Co.

Krapp, A. (1999). Interest, motivation and learning: An educational-psychological perspective. European Journal of Psychology of Education, 14(1), 23-40.

Krashen, S. D. (1982). Principles and practice in second language acquisition California Pergamon Press Inc.

Krashen, S. D. (1985). The Input Hypothesis. London: Longman.

Lightbown, P. M., \& Spada, N. (2013). How languages are learned (4 ed.). Oxford: Oxford University Press.

McKay, P. (2006). Assessing young language learners. Cambridge: Cambridge University Press.

Nunan, D. (2004). Task-based language teaching. Cambridge: Cambridge University Press.

Patton, M. Q. (2002). Qualitative Research and Evaluation Methods. Thousand Oaks: Sage.
Piaget, J. (1970). The science of education and the psychology of the child. New York: Oxford.

Piaget, J. (1983). Piaget's theory. In P. Mussen (Ed.), Handbook of Child Psychology (4 ed., Vol. 1). New York: Wiley.

Prabhu, N. S. (1987). Second language pedagogy. Oxford: Oxford University Press.

Rangkuti, H. (2007, 28 ${ }^{\text {th }}$ October). Si lugu dan si malin kundang. Kompas.

Rixon, S. (1991). The role of fun and games activities in teaching young learners. In C. Brumfit, J. Moon, \& R. Tongue (Eds.), Teaching English to Children: From Practice to Principles (pp. 33-48). London: Collin ELT.

Ryan, R. M., \& Deci, E. L. (2000). When rewards compete with nature: The undermining of intrinsic motivation and self-regulation. In C. Sansone \& J. M. Harackiewicz (Eds.), Intrinsic and Extrinsic Motivation: The search for optimal motivation and performance. San Diego, San Francisco, New York, Boston, London, Sydney, Tokyo: Academic Press.

Shadily, H., \& Echols, J. M. (Eds.). (1992) Kamus lengkap. Jakarta: Gramedia Pustaka Utama.

Slatterly, M., \& Willis, J. (2003). English for primary teachers. Oxford: Oxford University Press.

Slavin, R. E. (2012). Educational psychology : theory and practice (10 ed.). Boston: Pearson.

Sugono, D. (2008). Kamus Besar Bahasa Indonesia. Jakarta: Pusat Bahasa.

Suyanto, K. K. E. (2004). Pengajaran Bahasa Inggris di sekolah dasar: Kebijakan, implementasi, dan kenyataan. Retrieved from Malang:

Taymur, M. (1950). Si lugu baik hati akhirnya jadi pemimpin tiran. Cairo: Dar el Ma'arif.

Ur, P. (1996). A Course in Language Teaching. Cambridge: Cambridge University Press.

Vygotsky, L. S. (1978a). Mind in society. Cambridge Mass: Harvard Universtiy Press.

Vygotsky, L. S. (1978b). Thought and language. Cambridge MA: MIT Press.

Wood, D., Bruner, J. S., \& Ross, G. (1976). The role of tutoring in problem solving. Journal of Child Psychology and Psychiatry, 17(2), 11. 